\title{
ARMY ANT RAID ATTENDANCE AND BIVOUAC-CHECKING BEHAVIOR BY NEOTROPICAL MONTANE FOREST BIRDS
}

\author{
SEAN O’DONNELL, ${ }^{1,3}$ ANJALI KUMAR, ${ }^{1}$ AND CORINA LOGAN ${ }^{2}$
}

\begin{abstract}
We quantified resident and migrant bird attendance at army ant swarm raids $(n=48)$ in a neotropical montane forest. All observations were during seasons when Nearctic migrant birds are present. Bird species differed in army ant raid-attending behavior. Resident bird species attended 2 to $54 \%$ of raids, while migrants attended at lower maximum frequencies ( 2 to $21 \%$ of raids attended per species). Some resident and migrant bird species attended raids more frequently than expected based on capture rates in mist-net studies and point-count density surveys. Army ant raid attendance may be a regular element of foraging behavior for some resident species, and important in the wintering ecology of some Nearctic migrant species. The bird species that attended raids most frequently were predicted to show behavioral specializations for exploiting army ant swarms. Eight resident bird species (but no migrants) performed a specialized behavior, bivouac checking, by which birds sample army ant activity. Resident bird species' frequencies of raid attendance were positively associated with frequency of checking bivouacs $(r=0.68)$. We hypothesize the absence of obligate army ant-following birds in montane forests has favored performance of specialized behaviors for exploiting army ant raids by some resident birds. Received 3 October 2009. Accepted 9 March 2010.
\end{abstract}

Neotropical army ants (Formicidae: Ecitoninae) are top predators, and a diverse array of animal species associate with army ant colonies (Franks 1982, Franks and Bossert 1983, Brady 2003, Koh et al. 2004). Birds attend army ant foraging-raids to feed on arthropods and small vertebrates that flee from the advancing ants. Birds primarily attend the swarm raids of Eciton burchellii and Labidus praedator (Willis and Oniki 1978, Wrege et al. 2005). Bird flocks at army ant raids often include multiple species, and their composition is largely distinct from sympatric mixed foraging flocks of insectivores (Willis 1972, Willis and Oniki 1978, Otis et al. 1986, Willson 2004, Peters et al. 2008).

Some bird species are obligate army ant raidattendants that obtain most or all of their food at army ant swarms (Willis and Oniki 1978, Swartz 2001, Willson 2004, Brumfield et al. 2007). Other bird species attend raids opportunistically (Swartz 2001, Chaves-Campos 2003). Opportunistic army ant raid-attending bird species vary in their reliance on army ants (Willis 1972, Willis and Oniki 1978). Obligate army ant-following birds are agonistic toward other birds at raids in lowland forests. This interference competition reduces the value of ant raids as a food source

\footnotetext{
${ }^{1}$ Animal Behavior Program, Department of Psychology, Box 351525, University of Washington, Seattle, WA 98195, USA.

${ }^{2}$ University of Cambridge, Department of Experimental Psychology, Cambridge CB2 3EB, United Kingdom.

${ }^{3}$ Corresponding author; e-mail: sodonnel@uw.edu
}

to other birds (Willis 1966, Willis and Oniki 1978, Brumfield et al. 2007).

Obligate army ant-following birds are poorly represented or absent from montane forests (Willis and Oniki 1978, Brumfield et al. 2007). There are no obligate army ant-following birds at our study site near Monteverde, Costa Rica (Kumar and O'Donnell 2007). Birds from a diverse array of families attend army ant raids in the Monteverde area, including some resident and Nearctic migrant species (henceforth migrants; Vallely 2001, Kumar and O’Donnell 2007). We hypothesized that some montane bird species would exhibit behavioral specializations for exploiting army ant raids in the absence of local competition from obligate army ant-following birds. We asked whether some montane bird species attend raids more often than expected as a first test of this hypothesis. The frequency of raid attendance varies among Monteverde area birds, but attendance frequency alone does not account for possible effects of local abundance (Vallely 2001, Kumar and O'Donnell 2007, Peters et al. 2008). We extended our previous analyses estimating the effects of species' relative abundance on army ant raid-attendance in this study. Bird abundance estimates were derived from previously published mist-net captures and point-count densities (Young et al. 1998, Jankowski et al. 2009).

We predicted the most frequent raid attendant birds would be more likely to exhibit specialized behaviors for exploiting army ant swarms (Willis 1972, Willis and Oniki 1978, Swartz 2001, Chaves-Campos 2003). We ascertained whether 
montane forest birds perform bivouac-checking behavior to test this prediction. Bivouac-checking birds visit Eciton burchellii temporary nests (bivouacs) as the ant foraging raids start in the morning, and again in the evening. Bivouacchecking birds may assess army ant-raid activity and direction in the morning, or whether ants are emigrating to a new bivouac site in the evening (Swartz 2001, Chaves-Campos 2003). We correlated bird species' frequencies of bivouac checking with their frequencies of attendance at army ant raids to examine whether raid attendance frequency and bivouac-checking behavior were associated among bird species.

\section{METHODS}

Study Site.-Our sample sites spanned the continental divide in the Tilarán Mountain Range near Monteverde, Puntarenas Province, Costa Rica $\left(10^{\circ} 18^{\prime} \mathrm{N}, 84^{\circ} 47^{\prime} \mathrm{W}\right)$. The Monteverde area includes forest reserves with adjacent privately held continuous forest and associated forest fragments (Guindon 1997, Haber 2000, Harvey 2000, Jankowski et al. 2009). We collected data in forests between $1,175 \mathrm{~m}$ above mean sea level ( $\mathrm{m}$ asl) and 1,580 $\mathrm{m}$ asl elevation on the Pacific slope, and between 985 and 1,680 $\mathrm{m}$ asl elevation on the Atlantic slope. Our raid attendance samples included four life zones (Holdridge life zone system; Holdridge 1966, Guindon 1997, Young et al. 1998, Young and MacDonald 2000).

Sampling Bird Flock Composition.-We collected data during seasons when migrants occur in the Monteverde area (Stiles and Skutch 1989, Garrigues and Dean 2007). The four field trips collectively spanned much of the period of migrant presence (mid-Sep to late May): 11 January-4 March 2005 (dry season), 5 October11 December 2005 (onset of late wet season/dry season), 19 December 2007-1 January 2008 (early dry season), and 7-10 April 2008 (late dry season). We observed birds at 48 army ant raids during these trips. The army ant raids involved three swarm-raiding army ant species (Eciton burchellii, $n=40$; Labidus praedator, $n$ $=5$; and L. spinninodis, $n=3$ ). We did not separate army ant species in our analyses as the Labidus species raids were distributed across all life zones, and army ant species had no measurable effect on attending bird flock composition in the Monteverde area (Kumar and O'Donnell 2007). We observed a maximum of one swarm per day and alternated sampling dates among elevations to minimize order effects. We treated each army ant swarm as an independent data point because observations were separated in space and time. Observations were made during the diurnal active raid period of surface-foraging army ants. Start times ranged from 0900 to $1600 \mathrm{hrs}$ local time (CST).

We located flocks of army ant swarm-attending birds or foraging army ant columns by searching along established trails. We walked to swarm raid fronts where birds fed and positioned ourselves at the best location for unobstructed viewing of the swarm front; this was usually off to one side and facing in the direction the swarm was moving. If the raid or the bulk of bird activity shifted location during observations we walked to a new observation spot while attempting to avoid disturbing the birds. We noted all bird species and the number of individuals that were present upon our arrival (Coates-Estrada and Estrada 1989). The observation sessions lasted for $1 \mathrm{hr}$ except when raid activity ceased, heavy rainfall began, or ants traversed impassable terrain $(\bar{x} \pm \mathrm{SD}$ observation time $=47 \pm 18 \mathrm{~min})$. We analyzed only those flocks for which all attending birds were identified to species.

We collected four types of data on bird flock composition and bird behavior at the army ant swarms. (1) Start and end time to the nearest min. (2) Latitude/longitude coordinates and elevation to the nearest $10 \mathrm{~m}$ asl were taken with a handheld Geographic Positioning System (GPS) unit or an air pressure altimeter. Elevations were confirmed from topographic maps. (3) We identified all birds seen in attendance to species based on plumage appearance, behavior, relative body size, geographic range, and vocalizations (Stiles and Skutch 1989, Garrigues and Dean 2007). A bird had to be observed collecting prey that was fleeing from ants to be counted as an attendant. Birds were categorized as residents or migrants. (4) We recorded the number of individuals of each bird species present. The birds were not banded and we could not distinguish individuals that left the raid and returned from newly arriving swarm attendants. Thus, we used the maximum number of individuals that were observed simultaneously as a conservative estimate of the number of attending birds from each species (Coates-Estrada and Estrada 1989).

Bivouac-checking Observations.-We conducted 15 systematic watches for bivouac-checking behavior at E. burchellii bivouacs following 
Swartz (2001). We sat on the ground or on folding chairs at sites 5 to $10 \mathrm{~m}$ from the bivouac, facing the entrance of the bivouac shelter. We chose locations that were partially concealed by vegetation but had an unobstructed view of the bivouac entrance. Our observation durations ranged from 60 to $120 \mathrm{~min}(\bar{x}=87.4 \mathrm{~min} / \mathrm{session} ; 21.9 \mathrm{hrs}$ of observation). Like Swartz (2001), we conducted 12 observation sessions in the morning (start times 0440 to $0800 \mathrm{hrs}$ ) and extended the protocol by conducting three bivouac watches in the afternoon (start times 1533 to $1630 \mathrm{hrs}$ ). We recorded bivouac-checking behavior and counted a bird as checking the bivouac if it first flew toward the bivouac site and perched within $5 \mathrm{~m}$ of the bivouac. The bird then had to either peer at the bivouac shelter entrance, or land among the ants when ants were active outside the bivouac to be counted. We noted bird arrival time to the nearest minute and, whenever possible, recorded the duration of each bird's visit. We also recorded the species identity of birds that were observed performing bivouac-checking behavior while we were collecting other data $(n=5$ observations; Swartz 2001). We used the same behavioral criteria for bivouac checking as during systematic observations. Dates of bivouac-checking observations were: 15 November to 3 December 2005, 22 to 29 December 2007, 7 to 10 April 2008, and 5 to 25 July 2009. We made six systematic and two opportunistic bivouac-checking observations during seasons when Nearctic migrants are present at the field site.

We could not identify birds as individuals as birds were not banded and many species were sexually monomorphic in plumage. We used only one visit/species/observation session to estimate frequencies of bivouac checking. All but one of our bivouac-checking observations were in the premontane wet forest life zone. We sampled bivouac checking at elevations from 1,100 to $1,430 \mathrm{~m}$ asl; one systematic observation was conducted at a higher elevation $(1,575 \mathrm{~m}$ asl) in the lower montane wet forest life zone, but no birds were recorded bivouac checking at this site. We also noted if birds vocalized while bivouac checking in 2008 and 2009. We used observations of bird attendance at a larger sample of army ant raids $(n=54)$ for comparisons of raid attendance with bivouac checking. These data were collected during several field trips between 25 January 2005 and 10 April 2008. These raids partially overlap with the migrant season raid sample, but all were observed in the same life zone and over a similar range of elevations as our bivouac checking observations (1,100 to $1,475 \mathrm{~m}$ asl).

Statistical Analyses.-We calculated two measures of bird species attendance at swarm raids based on species richness and individual abundance at the 48 migrant season raids (CoatesEstrada and Estrada 1989): (1) the percent of raids at which each species was present, and (2) the percent of all raid-attending birds accounted for by each species. We used two independently collected data sets to estimate forest understory activity and relative abundance of bird species. We compared these with our abundance measure of army ant raid attendance (i.e., each species' percent of all birds at raids) to identify species that were present at raids more often than expected by chance. The estimate of relative activity came from mist-net data from Monteverde area forests (Young et al. 1998). We calculated the number of mist-net captures for each attending bird species from Young et al. (1998: table 2), summing total captures for each species over the four life zones that overlapped our sample area. Mist-net studies of bird abundance must be interpreted with caution (Remsen and Good 1996). For example, bird species may differ in probability of being caught in nets in the understory. We used an independently-derived estimate of relative abundance from standardized auditory and visual point-count data to complement the mist-net data. The point-count data also came from sites largely overlapping with our observations (Jankowski et al. 2009: supplementary table 1).

We followed Peters et al. (2008) to calculate two indices of raid attendance for each bird species. We regressed each species' proportion of the total birds observed at raids against its total captures in the mist-net studies (Young et al. 1998), and against its total/ha abundance estimated from point-counts (Jankowski et al. 2009). We calculated residuals from these two linear regressions and used the residuals as indices of raid attendance. We identified species as high-frequency army ant raid attendants when their index value (regression residual) was higher than the upper $95 \%$ confidence interval (CI) value from the corresponding linear regression model. We calculated the mist-net index separately for residents and migrants because resident birds were mist-netted year-round, including months when migrants are absent. We could not calculate 
a point-count index for migrants as they were not recorded in the point-count study, in part because migrants rarely vocalize outside their breeding ranges (Jankowski et al. 2009).

We asked whether bird species differences in raid attendance were correlated with bivouacchecking frequency. We calculated the Pearson correlation between an index of raid attendance frequency (i.e., the point-count attendance index) and bivouac-checking frequency for the 31 resident bird species observed at army ant raids in the bivouac-checking sample elevation range.

\section{RESULTS}

Bird Flock Composition at Ant Raids.-We observed 54 species of birds attending raids during the period of migrant presence (Table 1). The number of bird species in flocks at army ant raids ranged from one to $17(\bar{x} \pm \mathrm{SD}=4.73 \pm$ $3.27)$, while the number of migrant species ranged from zero to six $(0.79 \pm 1.29)$. We recorded 11 species of migrants attending raids; two were thrushes (Turdidae), one was a vireo (Vireonidae), and eight were wood warblers (Parulidae) (Table 1). We recorded 13 bird species at raids that had not been noted as army ant-raid attendants in the Monteverde area previously (11 new residents and 2 new migrants). Migrants participated in 21 $(43.8 \%)$ of the flocks at army ant swarms. None of the swarm-attending flocks were comprised only of migrants.

Resident Species Differences in Raid Attendance.-Resident bird species varied widely in frequency of raid attendance. Resident species ranged from 2.1 to $54.2 \%$ of army ant raids attended, and from 0.2 to $10.8 \%$ of the individual birds at army ant raids (Table 1). Species' pointcount densities and mist-net captures were positively but weakly correlated $(r=0.42, n=$ $54, P<0.01)$. These measures provide different information on bird species' baseline rates of occurrence in the habitat. Both measures of baseline density were non-significantly related to army ant-raid attendance by the 43 resident bird species. Point-count estimates of bird species' abundances were poor predictors of species occurrence at army ant raids $\left(R^{2}=0.004\right.$, df $=$ 53, $P=0.64)$. Similarly, capture frequency in mist-net studies was weakly associated with attendance at army ant raids $\left(R^{2}=0.06\right.$, df $=$ $42, P=0.10$ ). Both indices of frequency of raid attendance indicated strong species differences in frequency of army ant-raid attendance after accounting for density effects. There was high consistency between the two indices of which bird species attended army ant raids at higher than expected frequencies. Seven resident bird species' frequencies at raids exceeded the $95 \%$ CI value predicted by linear regression of raid attendance on mist-net capture frequency (Fig. 1). Six of these seven species (and one other) were significantly more frequent at raids than expected based on point-count densities (Fig. 1).

Migrant Species Differences in Raid Attendance.-Relative abundances of migrants at raids spanned an order of magnitude among species in terms of percent of raids attended (2.1 to $20.8 \%$ ) and in percent of individual birds seen at raids (0.19 to $1.87 \%$; Table 1$)$. The Kentucky Warbler (Oporonis formosus) was the most frequent migrant at army ant raids by both measures. Mist-net capture frequency of migrant species was a poor predictor of their proportion of raidattending birds $\left(R^{2}=0.07, n=11, P=0.43\right)$. Examination of residuals from this analysis suggests three migrant bird species attended raids more frequently than expected by mist-net captures (Fig. 2).

Bird Species that Check Bivouacs.-We observed eight species of birds from eight families checking bivouacs in the Monteverde area (Table 1). Birds checked bivouacs during 10 of the 15 systematic watches (67\%); birds were seen bivouac checking during $67 \%$ of both morning and afternoon watches. The number of species seen during an observation session ranged from zero to four ( $\bar{x}=1.47$ species). We did not see more than one individual of a given species arrive at the same time. Birds of three species were present at a bivouac simultaneously on one occasion, but were not seen interacting. Six species checked bivouacs both in the morning and afternoon (Table 1); the other two species checked in the morning but were seen only once.

Bird Behavior During Bivouac Checks.-We obtained duration data for 17 bivouac checks by six bird species (the bird was not identified on one timed visit). Bivouac-check durations pooled across species varied from a few seconds to several minutes (range $=5$ to $360 \mathrm{sec} ; \bar{x} \pm \mathrm{SD}=$ $103 \pm 126 \mathrm{sec})$. Visit lengths did not differ significantly among species (Kruskal-Wallis test, $X^{2}=7.6$, df $=5, P=0.18$ ).

Three species, Orange-billed NightingaleThrush (Catharus aurantiirostris), Rufous-andwhite Wren (Thryothorus rufalbus), and Rufous- 
TABLE 1. Frequencies of occurrence of birds as foragers at army ant swarm raids in montane forests near Monteverde, Costa Rica. Nearctic migrants are indicated by an asterisk *. Species not seen in previous studies of avian army ant raid attendance in the Monteverde area are indicated by a plus symbol + .

\begin{tabular}{|c|c|c|c|c|}
\hline Species & $\begin{array}{l}\text { Number of raids attended } \\
\qquad(n=48)\end{array}$ & $\begin{array}{l}\% \text { of raids } \\
\text { attended }\end{array}$ & $\begin{array}{l}\text { Number of birds } \\
\quad(n=316)\end{array}$ & $\begin{array}{l}\% \text { of } \\
\text { birds }\end{array}$ \\
\hline $\begin{array}{l}\text { Orange-billed Nightingale-Thrush } \\
\text { Catharus aurantiirostris }\end{array}$ & 26 & 54.2 & 58 & 10.8 \\
\hline $\begin{array}{l}\text { White-eared Ground Sparrow } \\
\text { Melozone leucotis }\end{array}$ & 18 & 37.5 & 29 & 5.4 \\
\hline $\begin{array}{l}\text { Blue-crowned Motmot } \\
\text { Momotus momota }\end{array}$ & 15 & 31.3 & 21 & 3.9 \\
\hline $\begin{array}{l}\text { Brown Jay } \\
\quad \text { Cyanocorax morio }\end{array}$ & 14 & 29.2 & 37 & 6.9 \\
\hline $\begin{array}{l}\text { Slaty-backed Nightingale-Thrush } \\
\text { Catharus fuscater }\end{array}$ & 10 & 20.8 & 21 & 3.9 \\
\hline $\begin{array}{l}\text { Rufous-and-white Wren } \\
\text { Thryothorus rufalbus }\end{array}$ & 10 & 20.8 & 13 & 2.4 \\
\hline $\begin{array}{l}\text { Rufous-capped Warbler } \\
\text { Basileuterus rufifrons }\end{array}$ & 10 & 20.8 & 11 & 2.1 \\
\hline $\begin{array}{l}\text { Kentucky Warbler } \\
\quad \text { *Oporornis formosus }\end{array}$ & 10 & 20.8 & 10 & 1.9 \\
\hline $\begin{array}{l}\text { Immaculate Antbird } \\
\text { Myrmeciza immaculata }\end{array}$ & 9 & 18.8 & 22 & 4.1 \\
\hline $\begin{array}{l}\text { Wood Thrush } \\
\text { *Hylocichla mustelina }\end{array}$ & 7 & 14.6 & 7 & 1.3 \\
\hline $\begin{array}{l}\text { Golden-crowned Warbler } \\
\text { Basileuterus culicivorus }\end{array}$ & 6 & 12.5 & 8 & 1.5 \\
\hline $\begin{array}{l}\text { Slate-throated Whitestart } \\
\text { Myioborus miniatus }\end{array}$ & 6 & 12.5 & 7 & 1.3 \\
\hline $\begin{array}{l}\text { Yellowish Flycatcher } \\
\text { Empidonax flavescens }\end{array}$ & 6 & 12.5 & 6 & 1.1 \\
\hline $\begin{array}{l}\text { Three-striped Warbler } \\
\text { Basileuterus tristriatus }\end{array}$ & 5 & 10.4 & 12 & 2.2 \\
\hline $\begin{array}{l}\text { Ruddy Woodcreeper } \\
\text { Dendrocincla homochroa }\end{array}$ & 5 & 10.4 & 7 & 1.3 \\
\hline $\begin{array}{l}\text { Wilson's Warbler } \\
\text { *Wilsonia pusilla }\end{array}$ & 5 & 10.4 & 7 & 1.3 \\
\hline $\begin{array}{l}\text { Swainson's Thrush } \\
\quad \text { *Catharus ustulatus }\end{array}$ & 5 & 10.4 & 5 & 0.9 \\
\hline $\begin{array}{l}\text { Blue-throated Toucanet } \\
\text { Aulacorhynchus prasinus }\end{array}$ & 4 & 8.3 & 6 & 1.1 \\
\hline $\begin{array}{l}\text { Chestnut-capped Brush Finch } \\
\text { Arremon brunneinucha }\end{array}$ & 4 & 8.3 & 4 & 0.8 \\
\hline $\begin{array}{l}\text { Ruddy-capped Nightingale-Thrush } \\
\text { Catharus frantzii }\end{array}$ & 4 & 8.3 & 4 & 0.8 \\
\hline $\begin{array}{l}\text { White-throated Thrush } \\
\text { Turdus assimilis }\end{array}$ & 3 & 6.3 & 8 & 1.5 \\
\hline $\begin{array}{l}\text { Azure-hooded Jay } \\
\text { Cyanolyca cucullata }\end{array}$ & 3 & 6.3 & 5 & 0.9 \\
\hline $\begin{array}{l}10 \text { species including one migrant: Black-and-white } \\
\text { Warbler *Mniotilta varia }\end{array}$ & 2 & 4.2 & 2 or 3 & 0.4 or 0.6 \\
\hline $\begin{array}{l}22 \text { species including } 6 \text { migrants*: Chestnut-sided } \\
\text { Warbler, +Dendroica pensylvanica; Black- } \\
\text { throated Green Warbler, D. virens, Ovenbird, } \\
\text { +Seiurus aurocapilla; Golden-winged Warbler, } \\
\text { +Vermivora chrysoptera; Canada Warbler } \\
\text { Wilsonia canadensis; Philadelphia Vireo, Vireo } \\
\text { philadelphicus }\end{array}$ & 1 & 2.1 & 1 or 2 & 0.2 or 0.4 \\
\hline
\end{tabular}




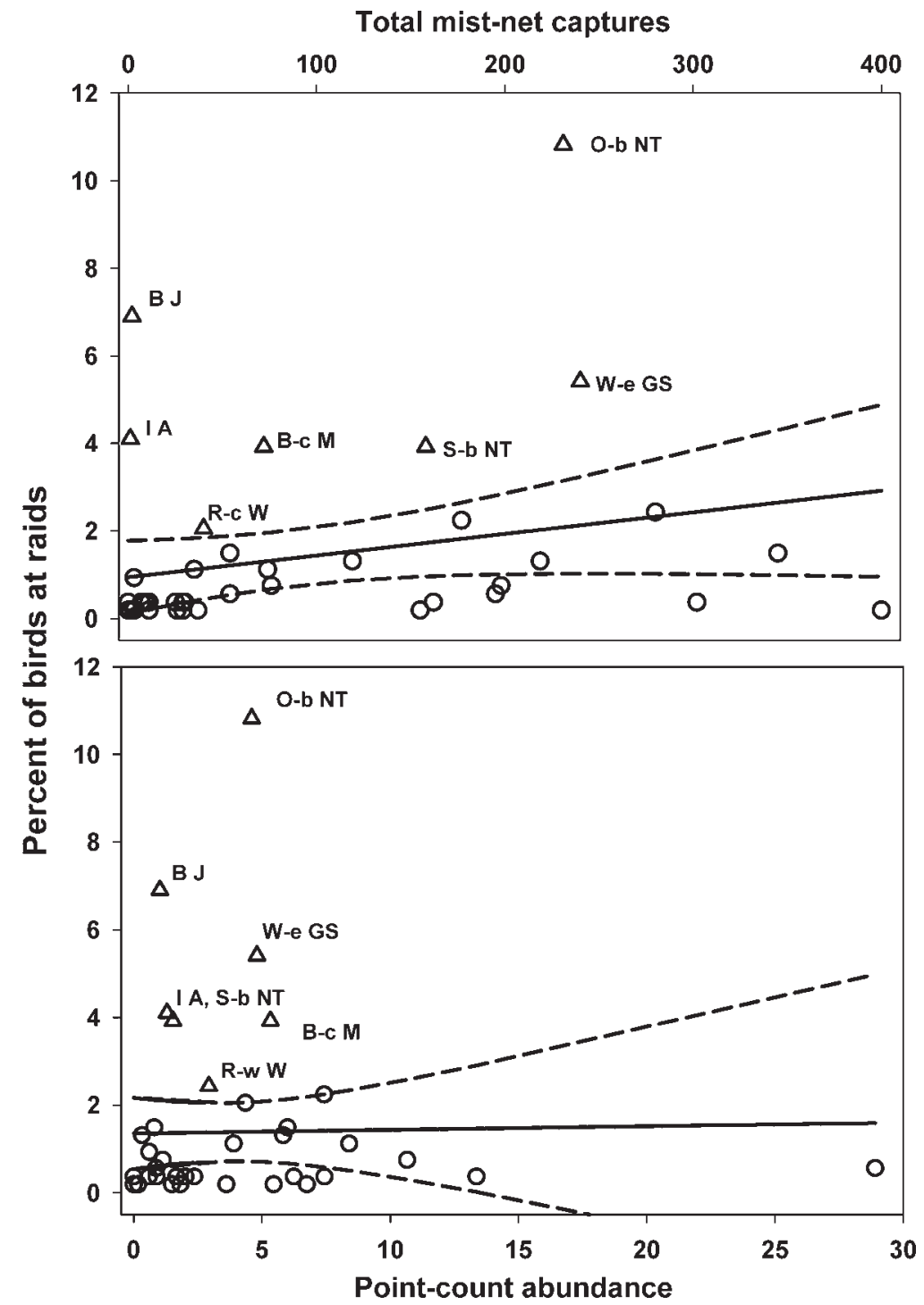

FIG. 1. Frequency of army ant raid attendance plotted against estimated local abundance for montane resident bird species (Monteverde, Costa Rica). Solid line: linear regression best fit. Curved dashed lines: 95\% confidence intervals (CI). Triangle symbols indicate species with raid attendance above the 95\% CI (O-b NT = Orange-billed Nightingale-Thrush; B $\mathrm{J}=$ Brown Jay; W-e GS = White-eared Ground Sparrow; IA = Immaculate Antbird; B-c M = Blue-crowned Motmot; S-b NT = Slaty-backed Nightingale-Thrush; R-c W = Rufous-crowned Warbler; R-w W = Rufous-and-white Wren).

capped Warbler (Basileuterus rufifrons), either sang or called while bivouac checking. Ruddy Woodcreepers (Dendrocincla homochroa) and/or Orange-billed Nightingale-Thrushes called or sang in the vicinity of bivouac sites during eight observation sessions, even when birds were not observed checking the bivouac. Individuals of these species apparently circled the bivouac site at distances of 10 to $15 \mathrm{~m}$, calling or singing from different perches.

Raid Attendance and Bivouac Checking.-Bivouac checking was associated with high frequencies of army ant raid attendance. We observed 42 species of birds attending 54 army ant raids in the elevation range where we sampled bivouac checking. All bird species that checked bivouacs 


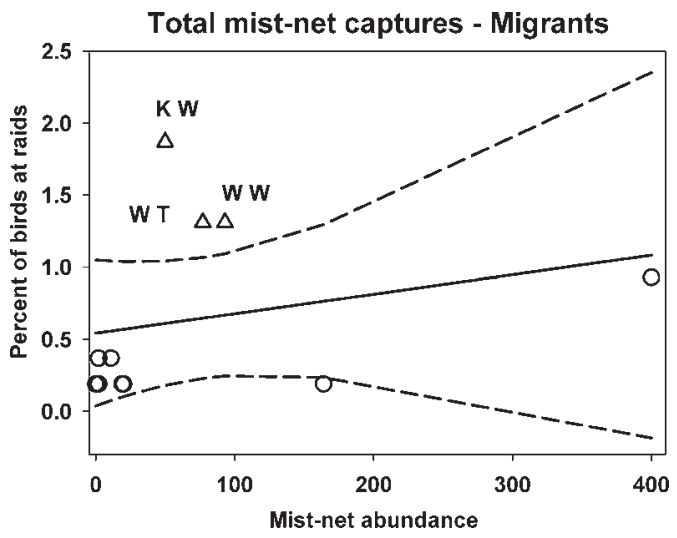

FIG. 2. Frequency of army ant raid attendance plotted against estimated local abundance for migrant bird species (Monteverde, Costa Rica). Solid line: linear regression best fit. Curved dashed lines: $95 \%$ confidence intervals (CI). Triangle symbols indicate species with raid attendance above the $95 \% \mathrm{CI}(\mathrm{KW}=$ Kentucky Warbler; WW = Wilson's Warbler; WT $=$ Wood Thrush).

were also seen attending ant raids. The eight species observed checking bivouacs were among the most frequent raid attendants (Table 2). Bivouac-checking birds represented $19.0 \%$ of the bird species at these raids, but $57.7 \%$ of individual birds at the raids. Furthermore, the percent of bivouacs checked by a species correlated positively $(r=0.68, n=31, P<$ 0.01 ) with the point-count raid attendance index for the 31 resident bird species that attended raids in the same elevation range (Table 2).

Six of our systematic watches and two opportunistic observations were in months when Nearctic migrant birds are wintering in the Monteverde area (Nov, Dec, and Apr.). No migrant birds were seen checking bivouacs (Table 2).

\section{DISCUSSION}

Resident Bird Species Differences in Raid Attendance.-Frequency of mist-net capture and point-count densities did not predict variation in raid attendance among bird species observed. Bird species density was not an important determinant of frequency of army ant-raid attendance, and bird species must vary in their frequency of raid attendance for other reasons. The two independently-derived indices of raid attendance for residents identified similar lists of bird species that were at raids more frequently than expected (Peters et al. 2008). These species may depend more heavily on army ants for food, and they may exhibit specialized behaviors for exploiting army ant swarms. These behaviors could include mechanisms for locating and orienting to the ants or to other attending birds, or abilities to track army ant colony activity and movements such as bivouac checking (Willis and Oniki 1978, Swartz 2001, Chaves-Campos 2003).

TABLE 2. Bird species observed attending army ant raids and checking bivouacs in montane forests near Monteverde, Costa Rica.

\begin{tabular}{|c|c|c|c|c|c|c|}
\hline Common name & Scientific name (Family) & $\begin{array}{c}\text { Percent of } \\
\text { bivouac check } \\
\text { observations } \\
(n=20)\end{array}$ & $\begin{array}{l}\text { Afternoon } \\
\text { bivouac- } \\
\text { checking } \\
\text { observed? }\end{array}$ & $\begin{array}{c}\begin{array}{c}\text { Percent of } \\
\text { raids } \\
\text { attended } \\
(n=54)\end{array}\end{array}$ & $\begin{array}{c}\text { Percent of } \\
\text { birds } \\
\text { at raids } \\
(n=327)\end{array}$ & $\begin{array}{c}\text { Raid } \\
\text { attendance } \\
\text { index rank } \\
(n=31 \text { species })\end{array}$ \\
\hline $\begin{array}{l}\text { Orange-billed Nightingale- } \\
\text { Thrush }\end{array}$ & $\begin{array}{l}\text { Catharus aurantiirostris } \\
\text { (Turdidae) }\end{array}$ & 50 & Yes & 59.3 & 20.2 & 1 \\
\hline Ruddy Woodcreeper & $\begin{array}{l}\text { Dendrocincla homochroa } \\
\quad \text { (Furnariidae) }\end{array}$ & 30 & Yes & 5.6 & 0.9 & 14 \\
\hline Rufous-capped Warbler & $\begin{array}{l}\text { Basileuterus rufifrons } \\
\quad \text { (Parulidae) }\end{array}$ & 15 & Yes & 35.2 & 7.6 & 5 \\
\hline Rufous-and-white Wren & $\begin{array}{l}\text { Thryothorus rufalbus } \\
\text { (Troglodytidae) }\end{array}$ & 15 & Yes & 24.1 & 5.5 & 6 \\
\hline Blue-crowned Motmot & $\begin{array}{l}\text { Momotus momota } \\
\text { (Momotidae) }\end{array}$ & 10 & Yes & 38.9 & 8.9 & 4 \\
\hline Blue-throated Toucanet & $\begin{array}{l}\text { Aulacorhynchus prasinus } \\
\text { (Ramphastidae) }\end{array}$ & 10 & Yes & 9.3 & 2.4 & 8 \\
\hline White-eared Ground Sparrow & $\begin{array}{l}\text { Melozone leucotis } \\
\text { (Emberizidae) }\end{array}$ & 5 & No & 48.1 & 11.9 & 2 \\
\hline Chirqui Quail-Dove & $\begin{array}{l}\text { Geotrygon chiriquensis } \\
\quad \text { (Columbidae) }\end{array}$ & 5 & No & 1.9 & 0.3 & 26 \\
\hline
\end{tabular}


Ecological Implications of Bivouac-checking Behavior.-Only obligate army ant-following birds checked bivouacs in lowland neotropical forests, even at sites with opportunistic species that frequently attended raids (Swartz 2001, Chaves-Campos 2003). Swartz (2001) suggested bivouac-checking behavior can be used to distinguish obligate army ant-following bird species from opportunistic raid attendants. Performance of this specialized behavior by Monteverde resident birds indicates army ant swarms are an important food resource to some montane bird species. The relative importance of foraging at ant raids to bird diets has not been quantified, but species differences in raid attendance combined with bivouac-checking behavior indicate some specialization for foraging at army ant swarms. Two bird species were seen checking bivouacs only once, indicating that more montane birds would be seen performing this behavior with additional observations. Whether resident and migrant montane birds exhibit other specialized behaviors to enhance attendance at ant raids requires further study. Some resident attendants vocalized while checking bivouacs, including nightingale-thrushes (Catharus spp.). Calling and singing at bivouac sites by some residents may recruit other birds to attend raids (Chaves-Campos 2003).

Bivouac-checking birds devote time and energy to sampling army ant behavior without an immediate food reward, and possibly expose themselves to predators. Bivouac-checking bouts were generally short in duration, consistent with this behavior incurring some cost (Swartz 2001). Some bird species check bivouacs in the morning (at the start of raiding) and in late afternoon (when most colony emigrations begin: O'Donnell et al. 2009), suggesting that birds track movements of ant colonies as well as their daily raiding activity. Individually marking and tracking birds will be necessary to identify how many bivouacs the montane resident birds check on a given day, and how far they travel among bivouacs (Willson 2004, Chaves 2008).

We hypothesize that reduced (or absent) competition with obligate army ant-following birds in some montane forests removes biotic constraints on specialized raid-attending behavior for other species. Reasons for obligate army antfollowing bird absence in the Monteverde area Pacific slope are not known, but lack of local competition with obligate army ant-following birds may enhance the value of army ant swarms to opportunistic raid-attending birds. It remains to be tested whether these behaviors represent local evolutionary adaptations or plastic expression of behavior based on learning or cultural transmission. We predict that observations at other sites without obligate army ant-following birds will reveal specialized army ant raid-attending behaviors in additional bird species.

Ecological Implications of Migrant Raid Attendance.-Three species of migrants attended army ant raids more often than expected according to the mist-net capture-based index. The Kentucky Warbler and two thrushes (Wood Thrush [Hylocichla mustelina] and Swainson's Thrush, [Catharus ustulatus]) have been recorded as army ant-raid attendants from Mexico to Colombia (Willis 1966, 1984, Greene et al. 1984, CoatesEstrada and Estrada 1989, Roberts et al. 2000, Meisel 2004), as have several other migrants we observed attending army ant swarms (Willis 1966, Hardy 1974, Greene et al. 1984, Roberts et al. 2000, Meisel 2004, Rios et al. 2008). Army antraid attendance is apparently consistent across the wintering ranges of some migrant birds. Swarmraiding army ants do not occur in the breeding ranges of the migrants we recorded as raid attendants (Watkins 1985). Attendance at army ant raids by wintering migrants is a striking example of plasticity in foraging behavior, and of differences in foraging ecology between breeding and wintering habitats. Changes in foraging ecology are an important component of nicheswitching between breeding and wintering sites (Nakazawa et al. 2004). Studies at South American sites are needed to learn if similar changes in foraging ecology, including army ant-raid attendance, are exhibited by Austral migrant birds (Jahn et al. 2004).

Migrants were not at raids without residents. Residents may initiate raid-attending flocks that are later joined by migrants, possibly in part because residents are locally more abundant (Young et al. 1998, Jankowski et al. 2009). Some resident birds may also be more effective at locating or tracking army ant raids, in part due to specialized behaviors like bivouac checking. Migrants did not check bivouacs but could use other behavioral mechanisms for exploiting ant raids. Data on young migrant bird interactions with army ants during their first migration into the geographic range of these ants could reveal important developmental patterns, including roles 
of learning and social transmission in the performance of raid-attending behavior.

All of the migrants we observed at raids are known to forage on other resources while wintering (Willis 1966, 1984; Di Giacomo and Di Giacomo 2006; SO'D and AK, pers. obs.). However, even occasional reliance on army ant swarm-raids as a food source may have implications for migrant bird conservation. The extent of reliance of migrants on army ants as a food source may affect fitness of birds and winter survival by migrants based on changes in army ant density. Army ant-foraging behavior and population dynamics are strongly affected by forest clearing and forest fragmentation (Franks 1982, Meisel 2006, Kumar and O'Donnell 2009). Habitat change effects on wintering migrants could be exacerbated through changes in army ant communities (Koh et al. 2004).

\section{ACKNOWLEDGMENTS}

Thomas Soare and Sean Tully assisted with field observations. We thank Frank Joyce and Katy Van Dusen for continuing logistical support, and the many residents of the Monteverde area who informed us of army ant swarm activity and allowed access to their private lands for research. The Tropical Science Center, Ecolodge San Luis/ University of Georgia, Monteverde Conservation League, and the Monteverde Institute extended support and access to protected lands for data collection. Research was conducted under permits from the Ministry of the Environment and Energy, Republic of Costa Rica (Scientific Passports 0387 and 01667), and in accordance with the laws of the Republic of Costa Rica. We thank the Organization for Tropical Studies (OTS) for ongoing research support, including assistance in obtaining permits. This project was supported by a University of Washington ALCOR Fellowship and an OTS Post-Course Award to AK, and University of Washington Royalty Research Fund and NSF grants (IBN-0347315) to SO'D. National Geographic Television also supported the field research. Research was partially supported by the National Science Foundation while SO'D was working at the foundation. Any opinions, findings, and conclusions or recommendations are those of the authors and do not necessarily reflect the views of the National Science Foundation. Two anonymous reviewers made helpful comments that improved the paper.

\section{LITERATURE CITED}

BRADY, S. G. 2003. Evolution of the army ant syndrome: the origin and long-term evolutionary stasis of a complex of behavioral and reproductive adaptations. Proceedings of the National Academy of Sciences of the USA 100:6575-6579.

Brumfield, R. T., J. G. Tello, Z. A. Cheviron, M. D. Carling, N. Crochet, And K. V. Rosenberg. 2007. Phylogenetic conservatism and antiquity of a tropical specialization: army-ant-following in the typical antbirds (Thamnophilidae). Molecular Phylogeny and Evolution 45:1-13.

CHAVES-CAMPos, J. 2003. Localization of army-ant swarms by ant-following birds on the Caribbean slope of Costa Rica: following the vocalization of ant birds to find the swarms. Ornitologia Neotropical 14:289-294.

Chaves, J. 2008. Benefits of cooperative food search in the maintenance of group living in Ocellated Antbirds. Dissertation. Purdue University, West Lafayette, Indiana. USA.

Contes-EstradA, R. And A. EstradA. 1989. Avian attendance and foraging at army-ant swarms in the tropical rainforest of Los Tuxtlas, Veracruz, Mexico. Journal of Tropical Ecology 5:281-292.

Di Giacomo, A. S. AND A. G. Di Giacomo. 2006. Observations of Strange-tailed Tyrants (Alectrurus risora) and other grassland birds following army ants and armadillos. Journal of Field Ornithology 77:266268.

FRANKS, N. R. 1982. Ecology and population regulation in the army ant Eciton burchelli. Pages 389-395 in The ecology of a tropical forest: seasonal rhythms and long term changes (E. G. Leigh Jr., A. S. Rand, and D. M. Windsor, Editors). Smithsonian Institution Press, Washington D.C., USA.

FRANKS, N. R. AND W. H. BosserT. 1983. The influence of swarm raiding ants on the patchiness and diversity of a tropical leaf litter ant community. Pages 151-163 in Tropical rain forest: ecology and management (S. L. Sutton, T. C. Whitmore, and C. A. Chadwick, Editors). Blackwell Scientific Publications, Oxford, United Kingdom.

Garrigues, R. And R. DeAn. 2007. The birds of Costa Rica. Cornell University Press, Ithaca, New York, USA.

Greene, E., D. Wilcove, And M. McFarland. 1984. Observations of birds at an army ant swarm in Guerrero, Mexico. Condor 86:192-193.

GuINDON, C. F. 1997. The importance of forest fragments to the maintenance of regional biodiversity surrounding a tropical montane reserve, Costa Rica. Dissertation. Yale University, New Haven, Connecticut, USA.

HABER, W. A. 2000. Plants and vegetation. Pages 39-94 in Monteverde: ecology and conservation of a tropical cloud forest (N. Nadkarni and N. Wheelwright, Editors). Oxford University Press, New York, USA.

HARDY, J. W. 1974. Jays as army ant followers. Condor 76:102-119.

HARveY, C. 2000. Colonization of agricultural windbreaks by forest trees: effects of connectivity and remnant trees. Ecological Applications 10:1762-1773.

HoldRIDGE, L. R. 1966. The life zone system. Adansonia 6:199-203.

Jahn, A. E., D. J. LeVEy, AND K. G. Smith. 2004. Reflections across hemispheres: a system-wide approach to New World bird migration. Auk 121:10051013.

Jankowski, J. E., A. L. CieckA, N. Y. Meyer, AND K. N. RABENOLD. 2009. Beta diversity along environmental gradients: implications of habitat specialization in 
tropical montane landscapes. Journal of Animal Ecology 78:315-327.

KoH, L. P., R. R. DunN, N. S. SodHI, R. K. Colwell, H. C. PROCTOR, AND V. S. SMITH. 2004. Species coextinctions and the biodiversity crisis. Science 305:16321634.

Kumar, A. AND S. O’DonNell. 2007. Fragmentation and elevation effects on bird-army ant interactions in neotropical montane forest of Costa Rica. Journal of Tropical Ecology 23:581-590.

KumAR, A. AND S. O'DonNELL. 2009. Elevation and forest clearing effects on foraging differ between surfaceand subterranean-foraging army ants (Formicidae: Ecitoninae). Journal of Animal Ecology 78:91-97.

Meisel, J. E. 2004. The influence of microclimate and habitat area on the ecology of the army ant Eciton burchellii in tropical forest fragments. Dissertation. University of Wisconsin, Madison, USA.

Meisel, J. E. 2006. Thermal ecology of the neotropical army ant Eciton burchellii. Ecological Applications 16:913-922.

Nakazawa, Y., A. T. Peterson, E. Martinez-Meyer, AND A. G. NAVARRo-SigueNZA. 2004. Seasonal niches of Nearctic-neotropical migratory birds: implications for the evolution of migration. Auk 121:610-618.

O'Donnell, S., J. LattKe, S. Powell, and M. Kaspari. 2009. Species and site differences in neotropical army ant emigration behavior. Ecological Entomology 34:476-482.

Otis, G. W., S. C. Santana, D. L. Crawford, and M. L. HigGINS. 1986. The effect of foraging army ants on leaf-litter arthropods. Biotropica 18:56-61.

Peters, M. K., S. LikARE, AND M. KRAEMER. 2008. Effects of habitat fragmentation and degradation on flocks of African ant-following birds. Ecological Applications 18:847-858.

Remsen JR., J. V. AND D. V. Good. 1996. Misuse of data from mist-net captures to assess relative abundance in bird populations. Auk 113:381-398.

Rios, M., G. LONDOÑO, AND L. BIANCUCCI. 2008. Notes on birds that follow army ants in the Northern Andes. Ornitologia Neotropical 19:137-142.
Roberts, D. L., R. J. Cooper, And L. J. Petit. 2000. Use of premontane moist forest and shade coffee agroecosystems by army ants in western Panama. Conservation Biology 14:192-199.

Stiles, F. G. AND A. F. SkUtch. 1989. A guide to the birds of Costa Rica. Cornell University Press, Ithaca, New York, USA.

SwARTZ, M. B. 2001. Bivouac checking, a novel behavior distinguishing obligate from opportunistic species of army-ant following birds. Condor 103:629-633.

VALLELY, A. C. 2001. Foraging at army ant swarms by fifty bird species in the highlands of Costa Rica. Ornithologia Neotropical 12:271-275.

WATKINS II, J. F. 1985. The identification and distribution of the army ants of the United States of America (Hymenoptera, Formicidae, Ecitoninae). Journal of the Kansas Entomological Society 58:479-502.

WILLIS, E. O. 1966. The role of migrant birds at swarms of army ants. Living Bird 5:187-231.

Willis, E. O. 1972. The behavior of Plain-brown Woodcreepers, Dendrocincla fuliginosa. Wilson Bulletin 84:377-420.

WiLLIS, E. O. 1984. Neotropical thrushes (Turdidae) as army ant followers. Ciencia y Cultura 36:1197-1202.

WiLLIS, E. O. AND Y. ONIKI. 1978. Birds and army ants. Annual Review of Ecology and Systematics 9:243263.

WILLSON, S. K. 2004. Obligate army-ant-following birds: a study of ecology, spatial movement patterns, and behavior in Amazonian Peru. Ornithological Monographs 55:1-67.

Wrege, P. H., M. Wikelski, J. T. MANDEL, T. RASSWEILER, AND I. D. COUZIN. 2005. Ant birds parasitize foraging army ants. Ecology 86:555-559.

Young, B. E. AND D. B. MacDonald. 2000. Birds. Pages 179-222 in Monteverde: ecology and conservation of a tropical cloud forest $(\mathrm{N}$. Nadkarni and N. T. Wheelwright, Editors). Oxford University Press, New York, USA.

Young, B. E., D. Derosier, AND G. V. N. Powell. 1998. Diversity and conservation of understory birds in the Tilarán Mountains, Costa Rica. Auk 115:998-1016. 